\title{
INFRARED SIGNATURE SUPPRESSION SYSTEMS IN MODERN MILITARY HELICOPTERS
}

\section{Mateusz PASZKo*}

* Department of Thermodynamics, Fluid Mechanics and Aviation Propulsion Systems, Faculty of Mechanical Engineering, Lublin University of Technology, Nadbystrzycka Street 36, 20-618 Lublin m.paszko@pollub.pl

\begin{abstract}
Helicopters play an important role in air-to-ground fire covering and the short-distance air-to-air fights, as well as the anti-tank missions and battlefield force transferring. The detection and survivability of helicopters on a battlefield significantly depends on their infrared emissions level, as well as the methods, equipment and systems used by potential enemy. The automatic detection systems, recognition and identification of flying objects use among other the thermo-detection methods, which rely on detecting the infrared radiation emitted by the tracked object. Furthermore, due to low-altitude and relatively low flight speed, today's combat assets like missile weapons equipped with infrared guidance systems are one of the most important threats to the helicopters performing combat missions. Especially meaningful in a helicopter aviation is infrared emission by exhaust gases, egressed to the surroundings. Due to high temperature, exhaust gases are a major factor in detectability of a helicopter performing air combat operations. In order to increase the combat effectiveness and survivability of military helicopters, several different types of the infrared suppressor (IRS) have been developed. This paper reviews contemporary developments in this discipline, with particular examples of the infrared signature suppression systems.
\end{abstract}

Keywords: infrared, military helicopter, stealth, radiation suppression.

\section{INTRODUCTION}

While carrying out flight missions, helicopters emit electromagnetic radiation with two characteristic spectrums: radio and infrared to the surroundings. The radio radiation is due to generation of the variable electronic and magnetic fields by units and electronic devices operating on a helicopter board. Emission of infrared radiation is important in the optical wavelength range and it is mainly due to heat production processes on a helicopter's board. According to [1], main infrared emissions areas of the helicopter in flight can be divided into: 
- radiation of solids - including heat exchange inside gearbox, engine components, heat shields and nacelles,

- radiation of aerodynamically heated surfaces e.g. main rotor and tail rotor,

- radiation of exhaust gases - emitted into spherical area of helicopter environment,

- reflected radiation from exhaust stream, sunshine, skyshine and earthshine.

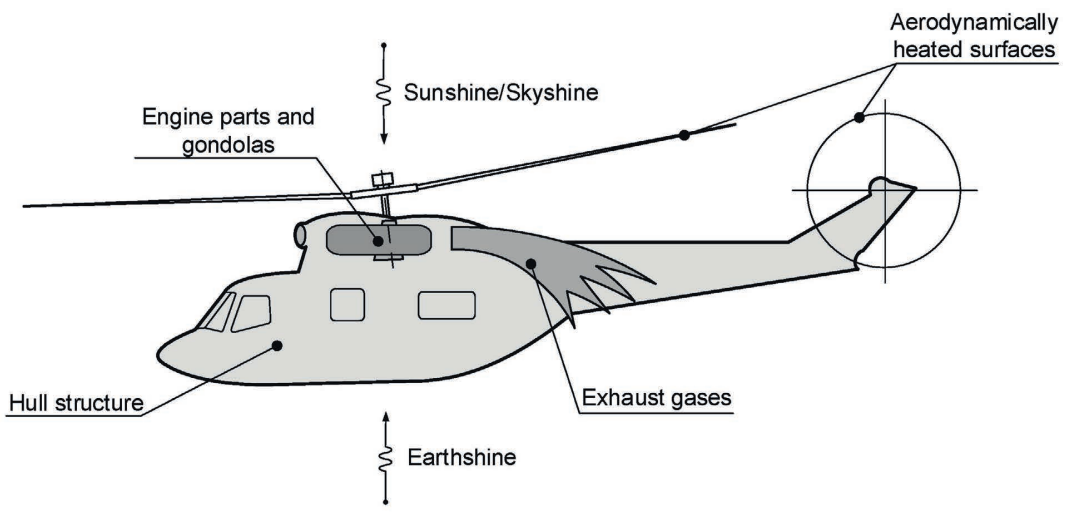

Fig. 1. Sources of IR signature of helicopter in flight, [2]

The arms race creates ever newer and more technically advanced detection, observation, tracking and infrared homing missile systems. This forces aircraft designers to design and adapt counter solutions to reduce the risks and consequences of a potential strike. Generally, the infrared sensing devices can be divided into two groups, which can complement each other:

- IRST (Infra Red Search and Track) - the infrared scanner primarily developed for object detection, localization and tracking and thermal mapping of land surface,

- FLIR (Forward Looking Infra Red) - the tracking and aiming devices, mainly to ground-air applications.

Modern military helicopters have a variety of the construction solutions aimed to reduce their potential detection in infrared and reduce the possibility of destruction by infrared-guided missiles. Helicopter protection systems can be divided into active and passive. The active protection serves only to throw infrared-guided missiles off the scent and is divided into two types: electrical equipment, sending a strong surge of electromagnetic radiation in the infrared spectrum that causes blindness to the missiles and heat devices like rocket flares - the heat traps hindering the missile finding the aim true position. A significant disadvantage of this type of protection is high cost. The electrical devices are fairly unreliable and consume high amounts of power. On the other hand, depending on their amount in the tray, flares always have a finite number. The passive infrared protection is a group of components integrated into the helicopter structure that include:

1. Fuselage surface shaping and coating with radar absorbent materials

2. Exhaust diffusers modifications

3. Engines shielding and nacelles modifications

4. Cooling of exhaust gases in special heat exchangers 


\section{RADAR ABSORBENT MATERIALS}

Radiation energy emitted on specified body surface, can be absorbed, reflected or transmitted through the body. In most of solid bodies e.g. metals, the radiation transmissivity is equal to zero. Earthshine reflected by the rear-fuselage skin is significant in dictating aircraft susceptibility to infrared-guided SAMs in the 8-12 $\mathrm{lm}$ band, but the role in the 3-5 $1 \mathrm{~m}$ band is insignificant. In the case against a SAM, the lower portion of the rear-fuselage skin is visible to the SAM. In the case of an AAM, the side portion of the rear-fuselage skin is visible. Therefore, different parts of the rear-fuselage skin should have different emissivity, for minimizing its infrared signature level against infrared-guided SAMs and AAMs, [3].

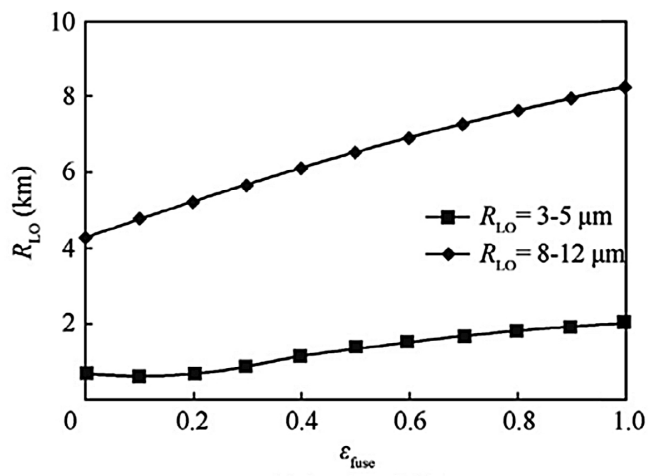

(a) Against SAM

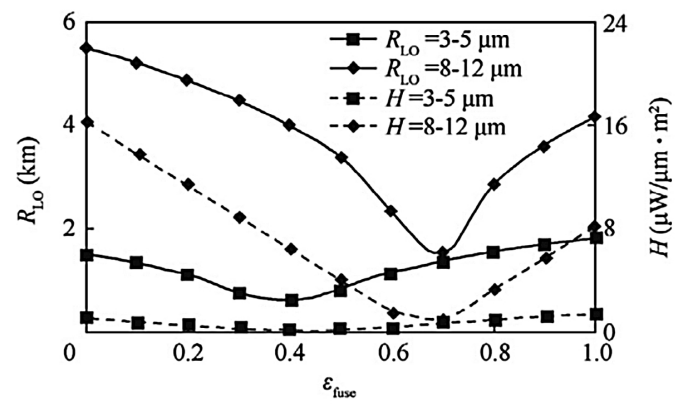

(b) Against AAM

Fig. 2. Effects of rear-fuselage skin emissivity on aircraft lock-on range and missile infrared irradiance, [4]

One feasible technique for reducing the infrared signature level from a metallic surface is the use of special Radar Absorbent Materials (RAM) which absorb part of the received electromagnetic energy and dissipate it to heat, thus reducing the reflected energy, [5]. Aircraft EM absorbers take several forms:

- structural materials and coatings specially designed for reduced radar reflectivity,

- coatings, including paints, specially designed for reduced or tailored reflectivity or emissivity in the microwave, infrared or ultraviolet spectra.

Most of the materials used for signature control were originally developed for military aircraft and are found on both fixed- and rotary-wing systems. Modified versions of the materials and treatment techniques are found on some ships, submarines, and ground combat and tactical vehicles[5,6]. This approach has been followed since WWII, where special paints containing carbon (an imperfect conductor) have been used to reduce the radar return of the snorkels of German submarines. Even though carbon is still being used for such purposes, today magnetic absorbers, based on compounds of iron, are preferred for operational systems, [7]. 


\section{EXHAUST DIFFUSERS MODIFICATIONS}

Temperature distributions on the fuselage skin and in the exhaust plume have a direct impact on infrared signature of helicopters [2]. Exhaust gases outflowing from the helicopter's engines to the surroundings, firstly create compact streams geometries but as a result of the rotor downwash impact they are developed in distinctive clouds around the back and bottom parts of the helicopter. It is also important to point that exhaust distribution in the surrounding of the fuselage is strictly depended on the helicopter flight maneuvering and weather conditions e.g. presence of the wind. The theoretical considerations on the spread in the environment and changes in the speed, temperature and concentrations of exhaust, outflowing from a helicopter turbine engine during chosen experimental flight maneuvers, were presented in [8]. Fig. 3 presents the chosen frame from video representing the PZL W-3 Falcon (with standard exhaust system) flight with visible zones of outflowing exhaust gases.

a)

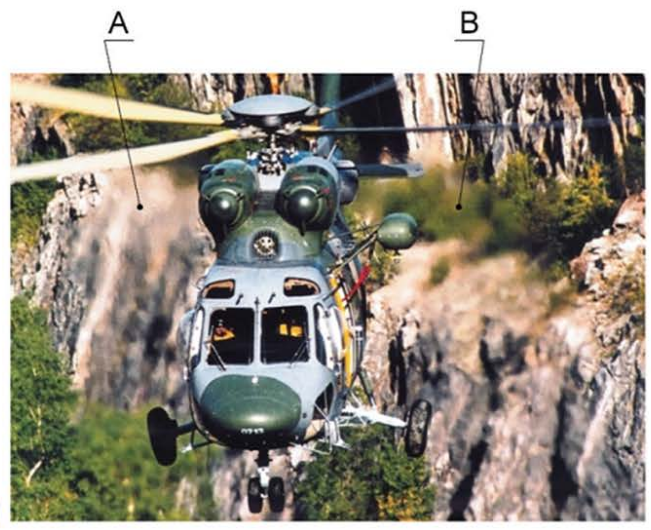

b)

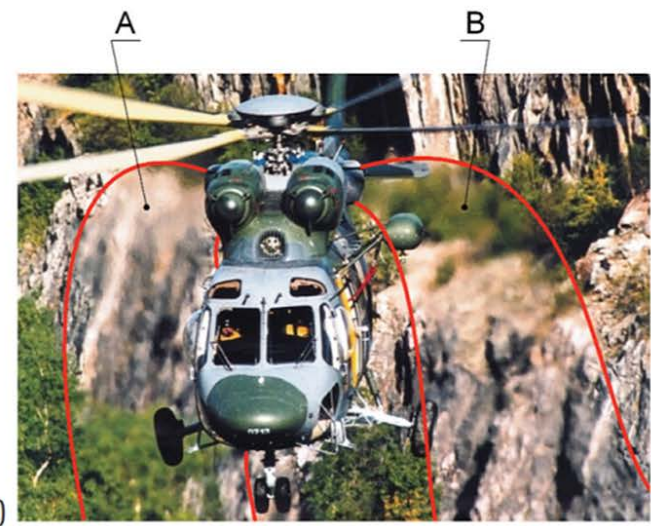

Fig. 3. PZL W-3 helicopter progressive flight in mountainous terrain with visible exhaust gases areas of both propulsion engines: A - windward side, B - leeward side, [8]

Fig. 4-6 present chosen results of the analysis of distribution of exhaust in various phases of PZL W-3 helicopter flight.

The results of the analysis on these phenomena were the basis for developing a simulation computer program, presented in [9]. The paper presents the 3D model and simulation of exhaust gases expansion in various vertical maneuvering of PZL W-3 helicopter in different speeds of side wind. Chosen results of a numerical simulation were presented in Fig. 7 and Fig. 8 below. 

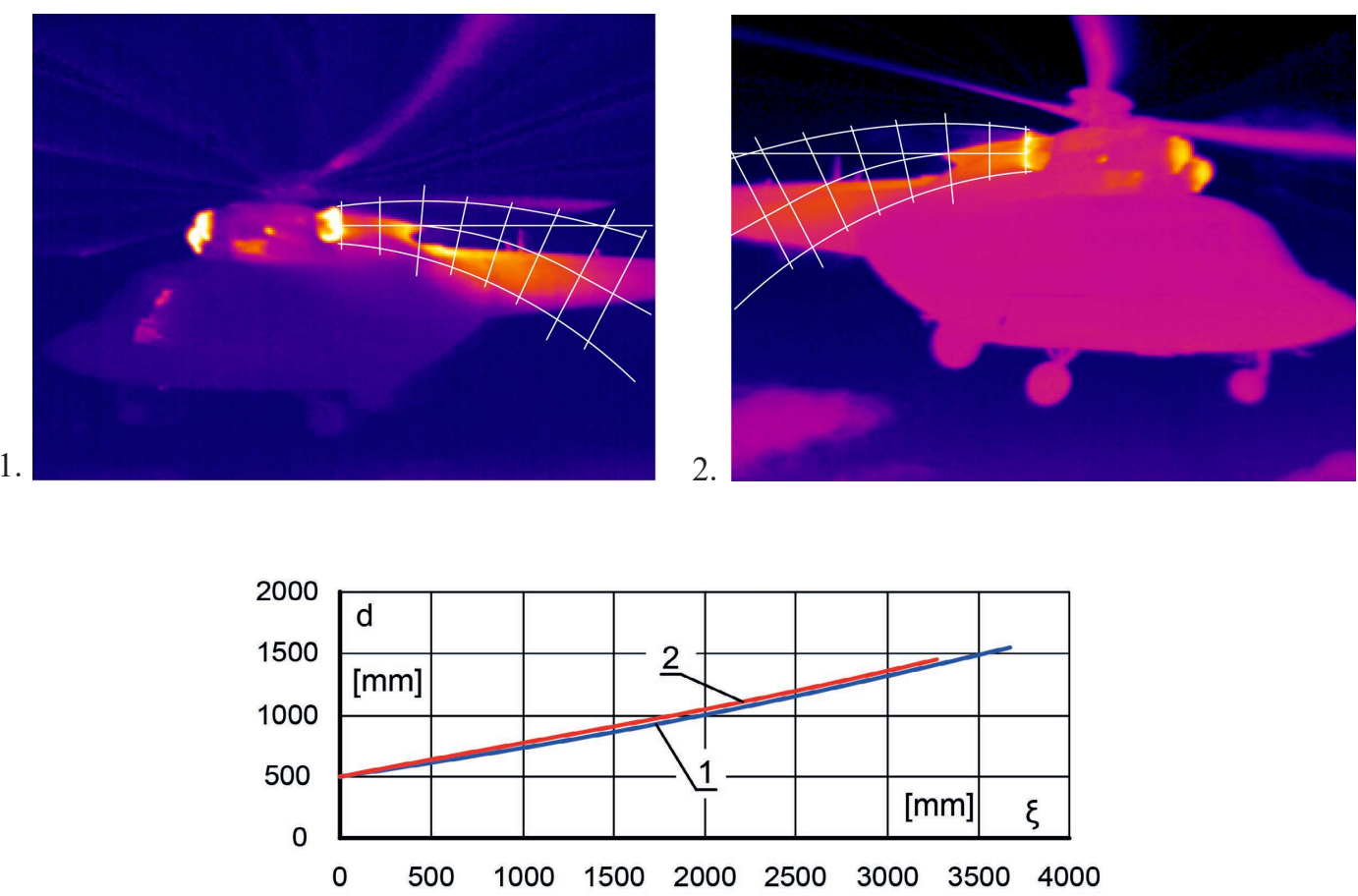

1 - left-side engine: $d=3 \cdot 10^{-5} \cdot \xi^{2}+0,1876 \cdot \xi+520,78 \mathrm{~mm}$

2 - right-side engine $d=1 \cdot 10^{-5} \cdot \xi^{2}+0,235 \cdot \xi+518,16 \mathrm{~mm}$

Fig. 4. Distributions and approximations of transverse dimensions of exhaust streams along the natural coordinates in level flight $-\mathrm{V}_{\mathrm{L}}=130 \mathrm{~km} / \mathrm{h},[2]$
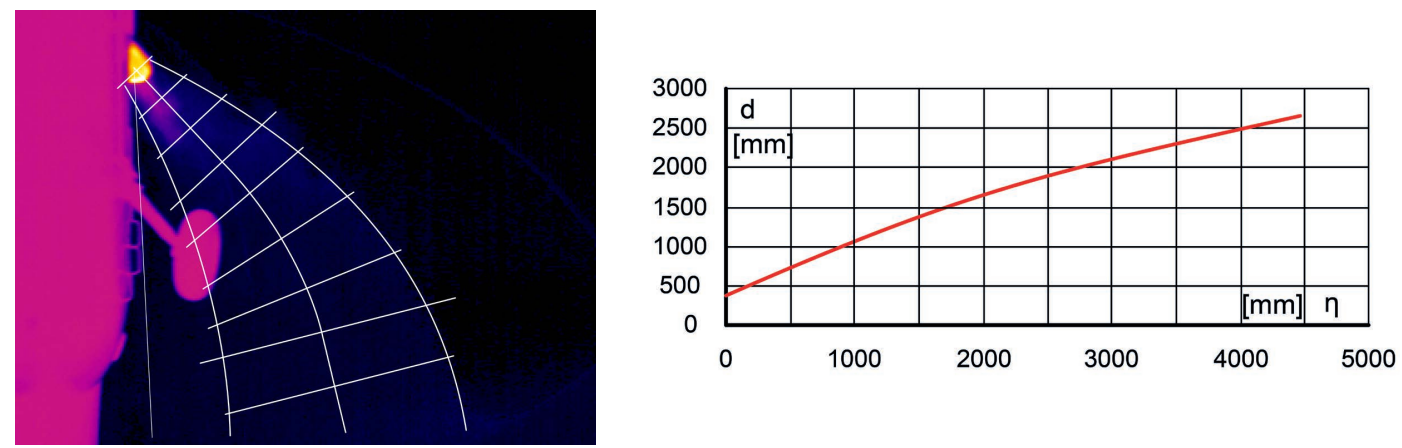

left-side engine: $d=-5 \cdot 10^{-5} \cdot \eta^{2}+0,7114 \cdot \eta+387,35 \mathrm{~mm}$

Fig. 5. Distribution and approximation of transverse dimensions of exhaust streams along the natural coordinate in hover $-\mathrm{V}_{\mathrm{L}}=0 \mathrm{~km} / \mathrm{h}, \mathrm{H}=15 \mathrm{~m},[2]$ 

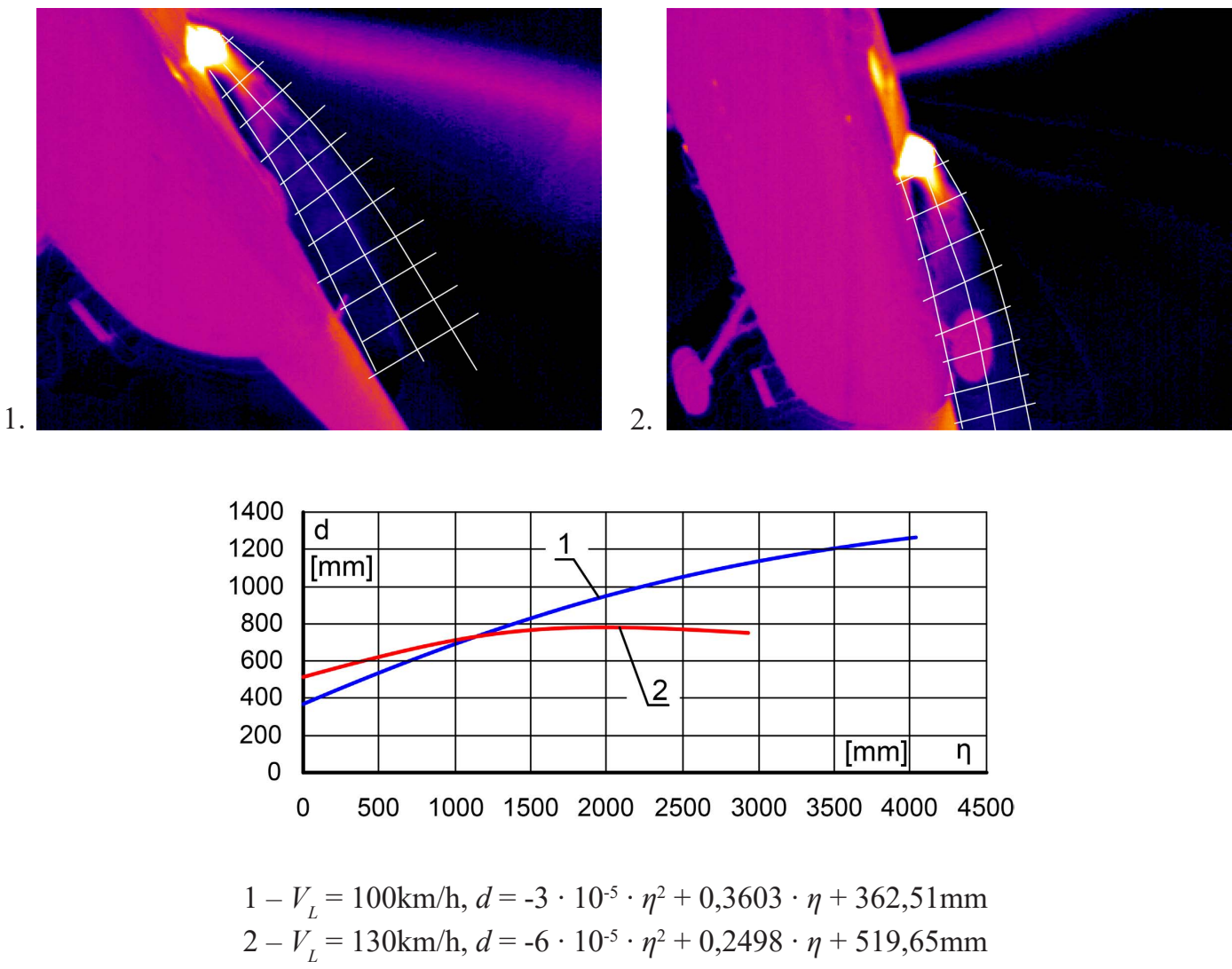

Fig. 6. Distributions and approximations of transverse dimensions of exhaust streams along the natural coordinates in level flight, $1-\mathrm{V}_{\mathrm{L}}=100 \mathrm{~km} / \mathrm{h}, 2-\mathrm{V}_{\mathrm{L}}=130 \mathrm{~km} / \mathrm{h}$, [2]
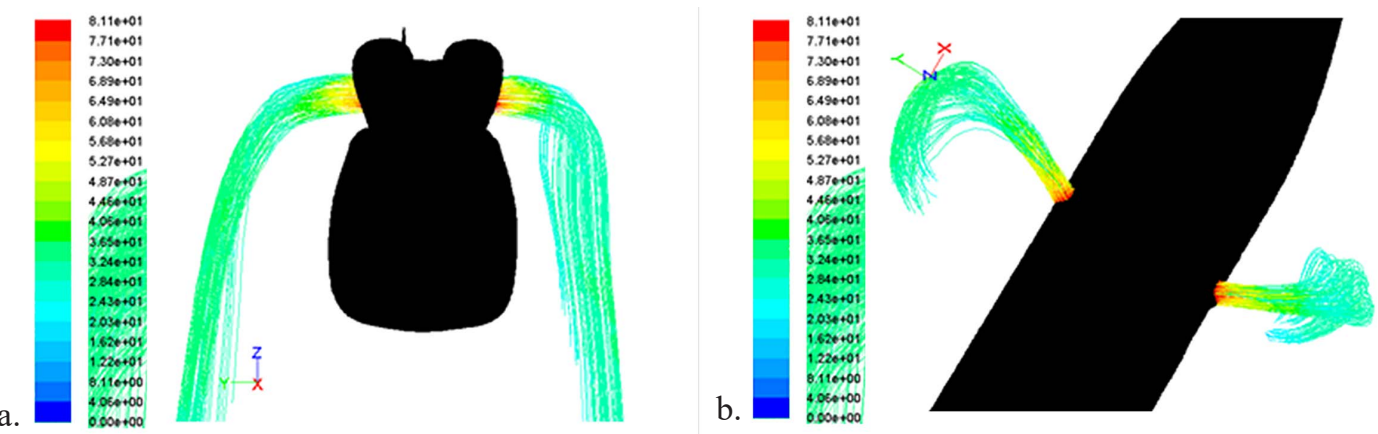

Fig. 7. Stream lines of exhaust outflowing from engine's diffusers for helicopter in hover without wind, a - front view, b- plan view, [9] 

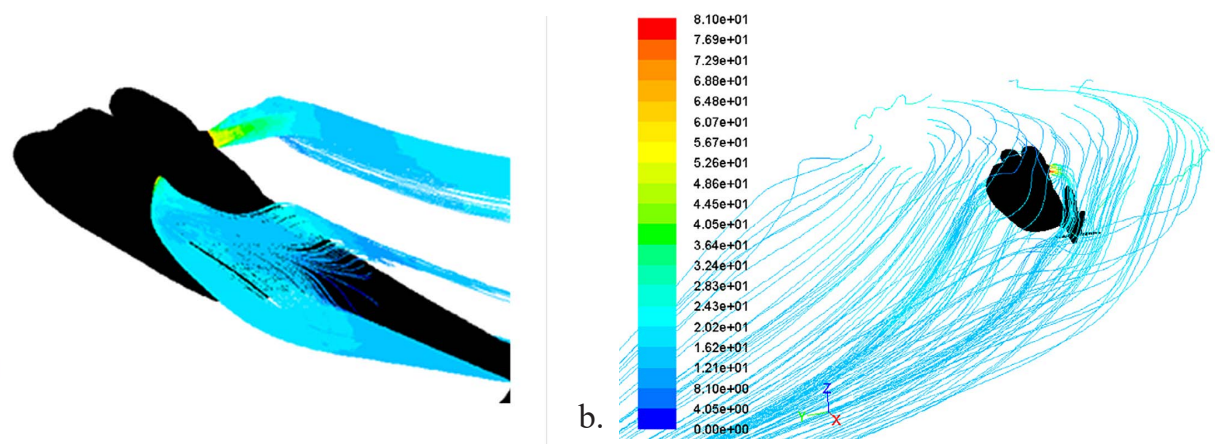

Fig. 8. Structures of exhaust streams for helicopter in hover with: a - head-wind at speed of $10 \mathrm{~m} / \mathrm{s}, \mathrm{b}-$ crosswind at speed of $10 \mathrm{~m} / \mathrm{s}$, [9]

According to [9], simulated streamlines and velocity distributions of the exhaust outflowing from the helicopter engines indicate presence of non-deflected (from the directions of the collector axes) dense parts of the streams at certain distances from the collectors outlet cross-sections. Such a configuration of exhaust streams is a result of the existence of a ,well of flow” in the downwash stream (exhaust manifolds are located in the zone of this well). Simultaneously, momenta and kinetic energies of the exhaust at the aforementioned distances are not yet subject to significant dislocations. Based on the visualization of the obtained streamlines distributions and flow velocities, significant changes in the behavior of the exhaust streams are observed beyond the dense areas. Under the influence of the downwash and the wind, the streams are deviated from the initial directions and deforms, which consequently leads to the scattering of exhaust in form of clouds in the distal area of the rotor downwash.

In order to limit turbine blades visibility, reduce emission from exhaust gases and also to avoid heating the tail boom, outlet diffusers are set under specific pitch to the longitudinal engine axis. Results of the simulation of the plume flow fields under downwash were presented in [10].

According to [3], the exhaust plume takes on strong downwards deflection to the rear fuselage, as well as deflection to the rotor's rotational direction, under the action of rotor downwash. These deflections are especially obvious under higher rotor downwash. When the exhaust is ejected upward, the exhaust plume could come into collision with the rear fuselage, and pumping capacity of the exhaust system is weakened a little. While the exhaust is ejected in oblique or lateral directions, the exhaust plumes do not come into collision with the rear fuselage, and pumping capacities of the exhaust system are somewhat enhanced. The exhaust direction shows significant influence on the infrared radiation distribution, as seen in Fig. 9. In this figure, downwash denotes the downwash velocity. When the exhaust is ejected in the oblique direction, the infrared radiation intensity detected from the top direction is almost the same as that from the lateral direction. While the exhaust is ejected upward or sideward, strong infrared radiation occurs at some viewing directions. 
Upward - turned exhaust

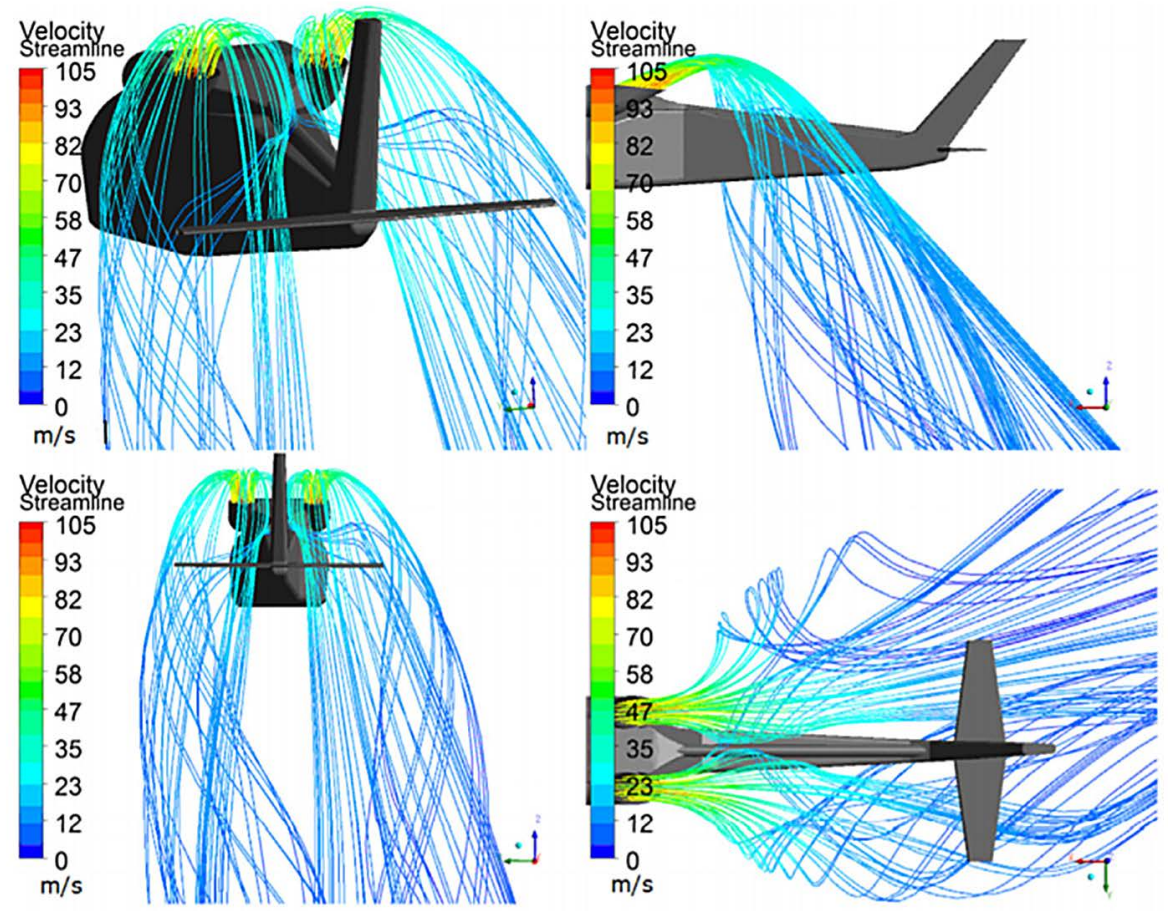

Oblique - turned exhaust

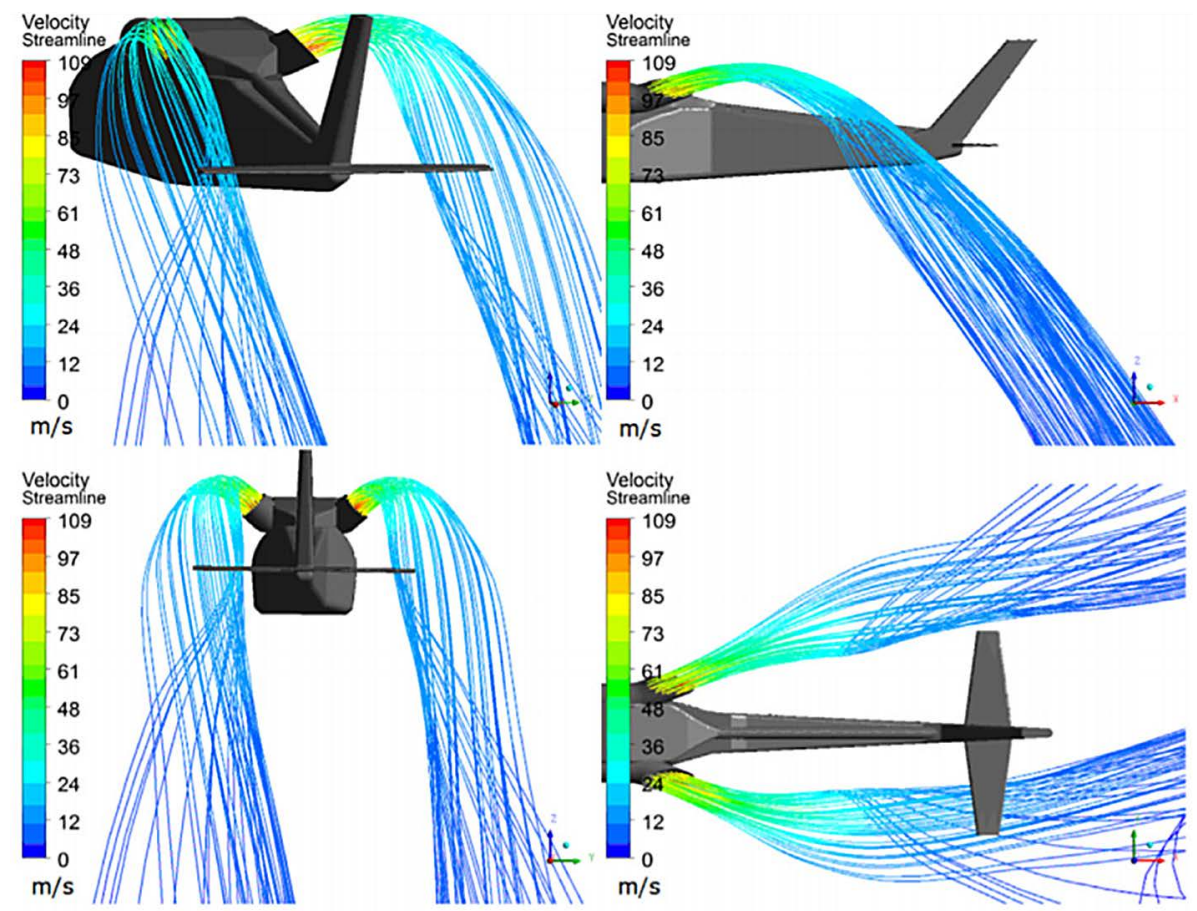


Lateral - turned exhaust

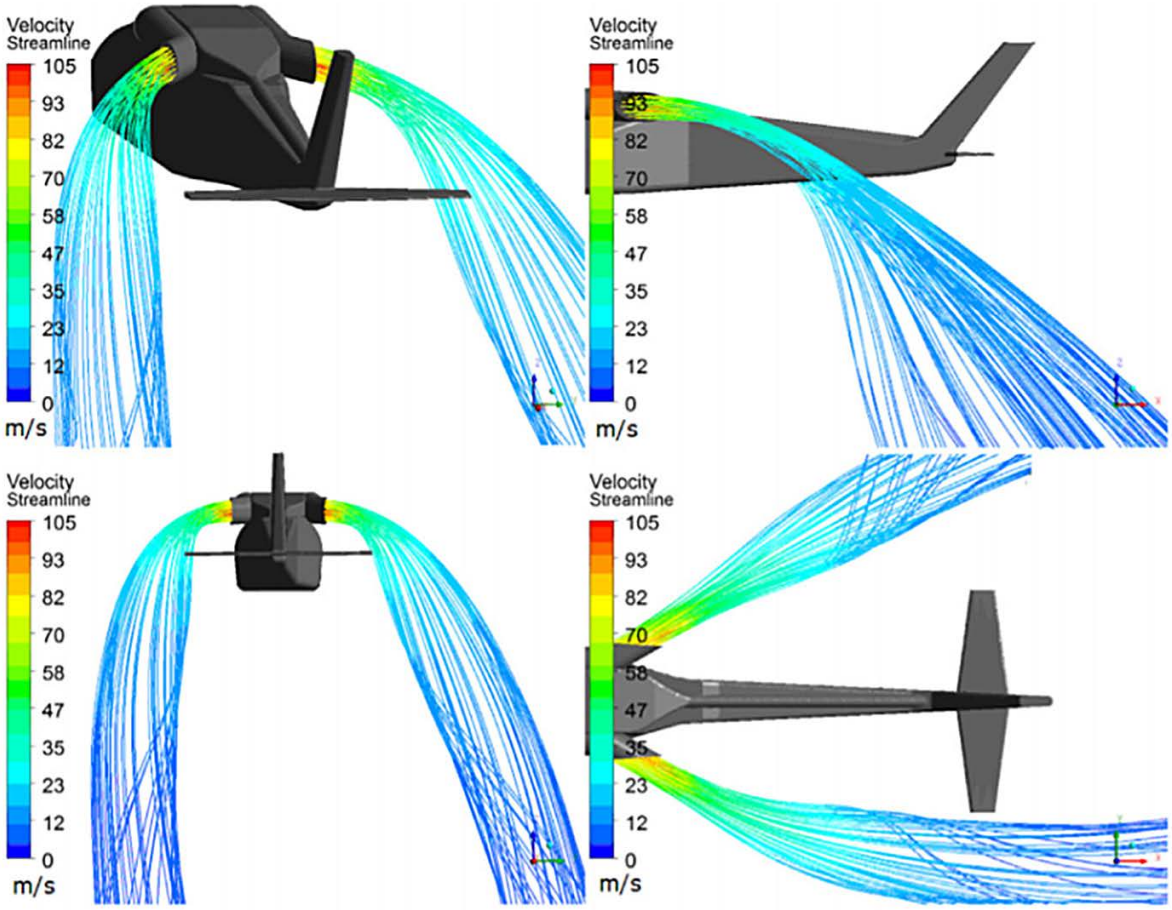

Fig. 9. Plume flow fields under downwash of $10 \mathrm{~m} / \mathrm{s}$ for different configurations of exhaust diffusers, [10]

An example of exhaust system modernization was $\mathrm{OH}$ - 58D Kiowa Warrior helicopter. Exhaust system has been located on the right side of the hull's upper surface and exhaust gases were directed upwardly. Modified exhaust outlet with exhaust cooler didn't result in an increase of the construction's mass and also didn't significantly affect the performance of the helicopter's engine. Mixing hot exhaust with rotor downwash resulted in a significantly lowered infrared emission. Fig. 10 shows the results of comparing the infrared emissions before and after modification of helicopter exhaust system.
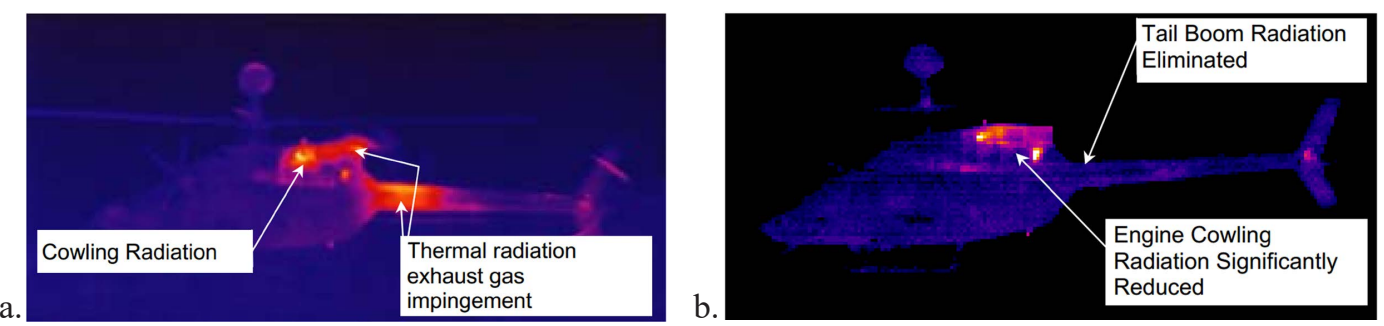

Fig. 10. OH-58D Kiowa Warrior in infrared, a - before modification, $b$ - with modified exhaust system, [11] 


\section{ENGINE SHIELDING AND NACELLES MODIFICATIONS}

Because of high power output with relatively low weight, turbine engines revolutionized the aviation industry. Nowadays turboshaft engines, remain an almost exclusive propulsion type in military helicopters. Transient temperature fields and temperature gradients that occur in all sections of the turbine engine, i.e. compressor, combustion chamber, turbine assembly and diffuser cause significant emissions of infrared radiation. Its presence results from the temperature difference between engine surface and the environment. The combustion process of fuel and air mixture continuously heats the surrounding surfaces and components of the engine. The most thermal loaded parts of a turbine engine are its first stage turbine blades. As a result of high temperature processes inside engine duct, large amounts of heat need to be discharged outside of the engine structure. Otherwise, the engine parts will overheat and get damaged. On the other hand, hot exhaust gases and heat emission from engines parts to the surroundings exposes an aircraft to high risk on a battlefield. Heat-seeking missiles and other modern combat assets are guided into the infrared glow of aircraft hot parts. Infrared stealth, requires that aircraft parts and emissions, particularly those associated with engines, have to be kept as cool as possible.

a.

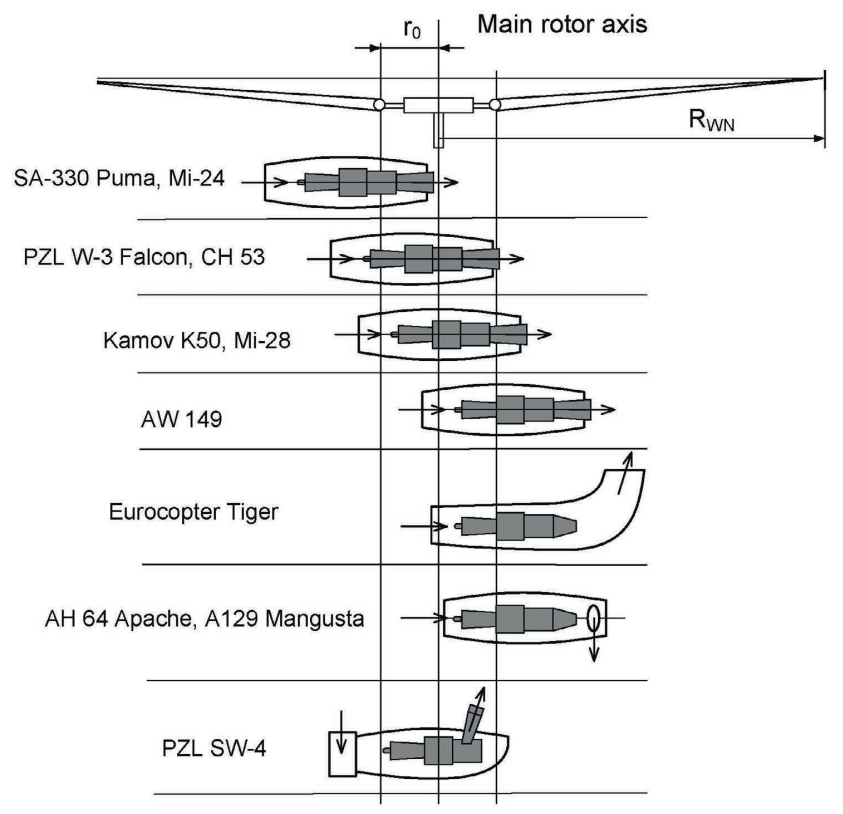

b.

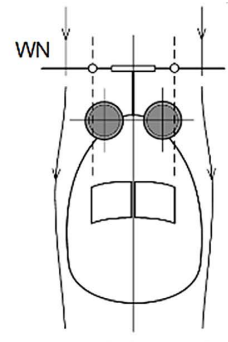

PZL W-3 Sokół

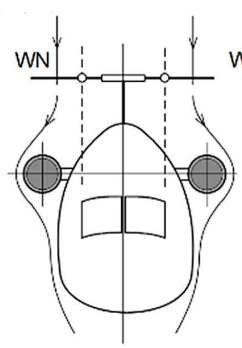

AH 64 Apache

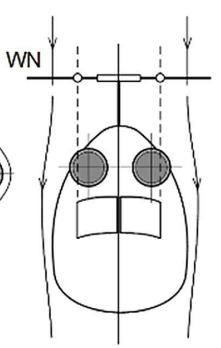

Eurocopter Tiger

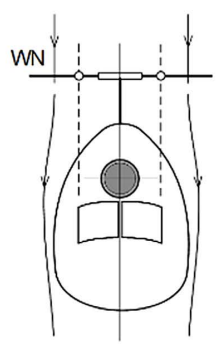

PZL SW-4

Fig. 11. Typical placement of turbine engine in actual helicopters: $a$ - in longitudinal planes , $b$ - in transverse planes, [12] 
Placement of engine in hull structure relative to the main rotor axis is important not only for cooling process but also engine smooth operation.

a.
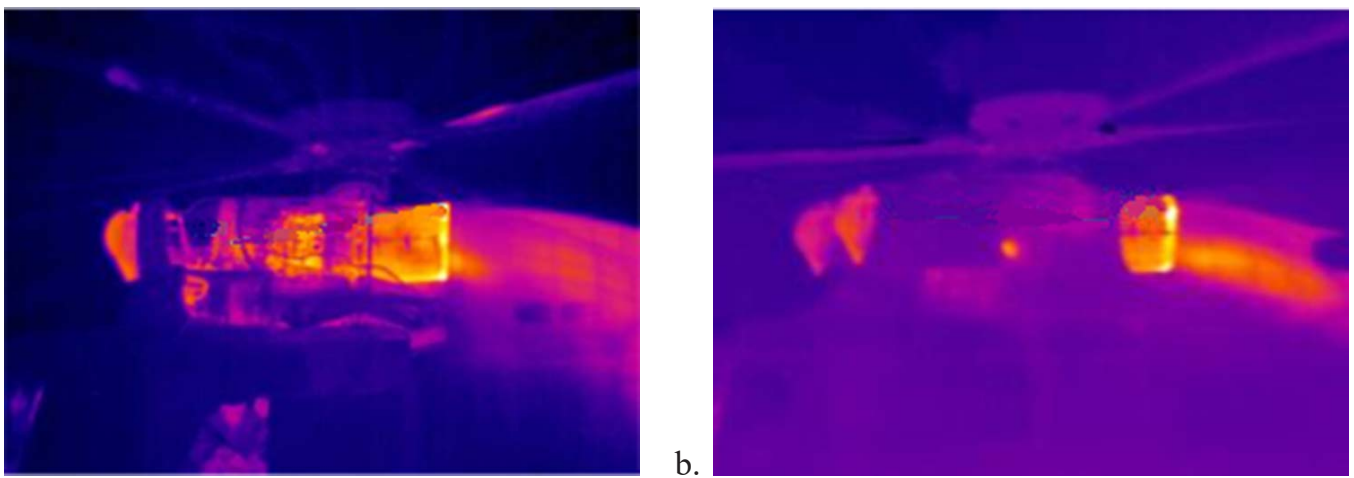

Fig. 12. PZL-10W turbine engine mounted on PZL W3 Falcon helicopter, a - with heat shield, $\mathrm{b}$ - without heat shield, [2]

Fig. 13 presents the temperature distribution along the engine inlet, surface of the gondola cover and exhaust gas diffuser at the helicopter take-off maneuver - the engine in take-off mode.
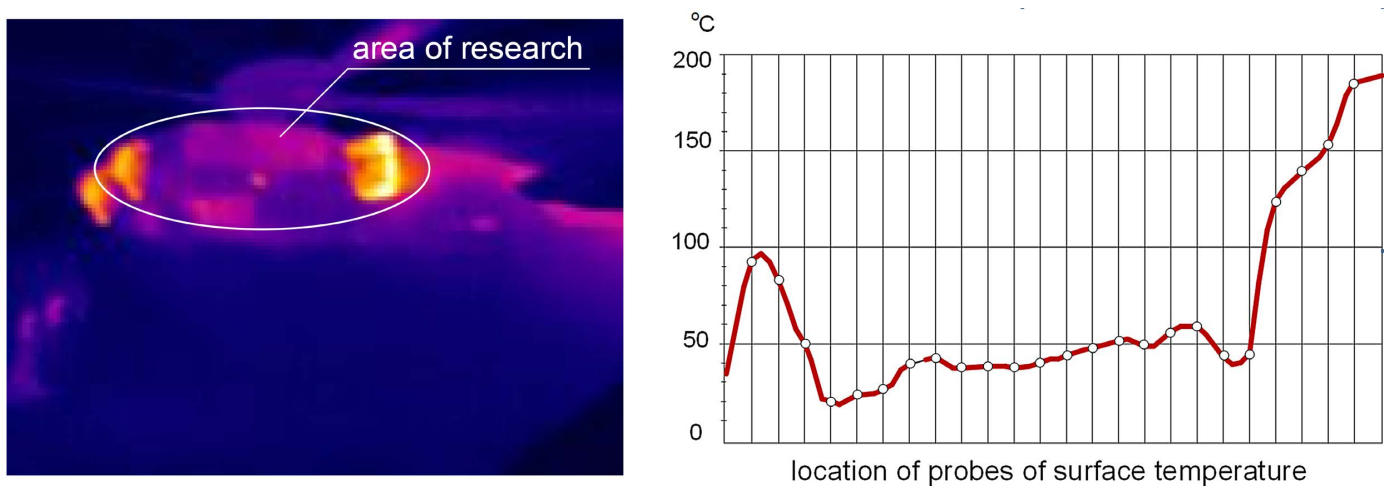

Fig. 13. Temperature distribution along the engine inlet, surface of the gondola cover and exhaust gas diffuser, [2]

Heat shields and nacelles are cooperating systems. Heat shields are used on most engines to protect components and bodywork from heat damage and nacelles from heating. Heat shields can be divided into rigid, flexible and textile. The rigid heat shields are usually made from aluminum, aluminum sheet or other composites, with a ceramic thermal barrier coating to improve the heat insulation. The flexible heat shield is normally made from thin aluminum sheeting though high performance flexible heat shields sometimes include extras, such as ceramic insulation applied via plasma spraying. There are also textile heat shields used for protection of various components 
such as electric wires, fuel system or other engine supporting systems. Usually the space between engine and nacelle creates a flow duct for engine and exhaust system cooling air. Cooling streams in engine internal parts can be generated in two ways:

1. By an additional fan driven from the engine shaft - the air flow is introduced inside by a system of channels

2. Through the use of uneven distribution of velocity and pressure in the rotor wake vortex

Fig. 14. presents cooling process of engine duct, supported by surrounding air flow and rotor downwash.
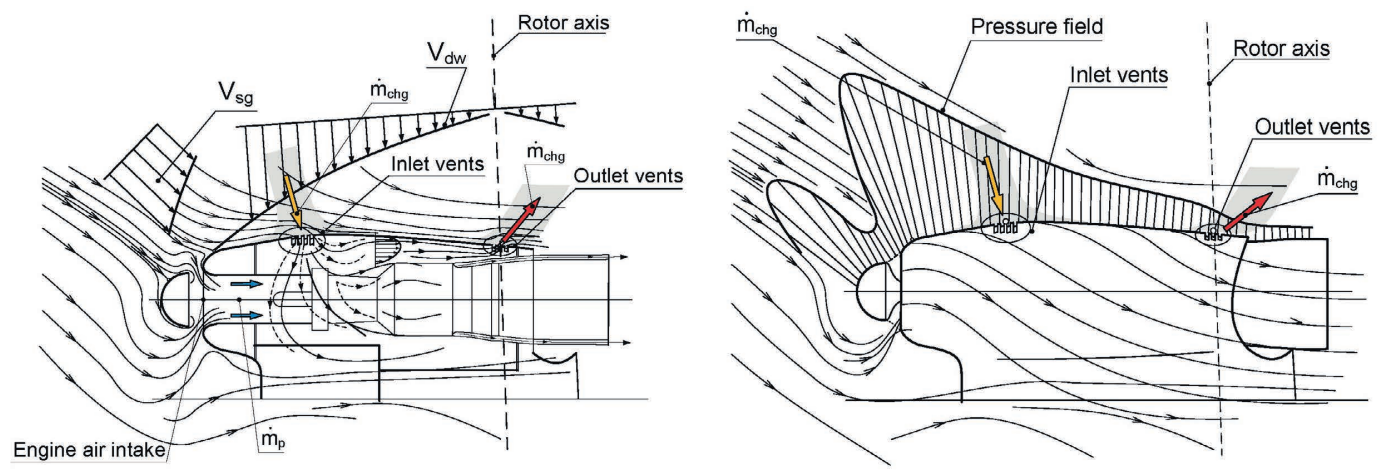

Fig. 14. Schematic flow around the nacelle zone with heat screen in PZL W-3 Falcon helicopter in level flight: $\mathrm{a}$ - cooling air flow inside nacelle duct, $\mathrm{b}$ - pressure distribution diagram on the nacelle surface, [12]

The nacelle structure has special holes for the purpose of capturing the rotor wake vortex and cooling engine parts. Such structured cooling process eliminates the possibility of deterioration of physical properties and durability of materials, reduce thermal loads of engine and its components and allows to obtain engine performance provided by the manufacturer. The flow of cooling air inside nacelle duct is caused by the pressure differences in the inlet and outlet vents, spread over the nacelle surface. Flow conditions of cooling air inside nacelle duct are mainly formed by flow velocities and static pressures in nacelle surrounding and influence of rotor downwash. The weather conditions under which the helicopter is operated create an additional impact on cooling process efficiency. Often, these conditions inhibit cooling process e.g. due to the high temperatures of atmospheric air.

\section{EXHAUST DESUPERHEATERS}

When designing new helicopter types, especially for combat applications, it is essential to pay enormous attention to infrared emissions of the solid parts composing the helicopter's structure, as well as to exhaust gases egressing from the engine's exhaust system. Due to their high temperature and significant amounts of carbon dioxide and water vapor, exhaust gases egressed to the surroundings are a major factor in infrared radiation emission and, in consequence, detectability of a helicopter performing air combat operations.

One of protection methods of a helicopter in flight is cooling the exhaust gasses, emitting from the engines to the atmosphere, in special heat exchangers. Nowadays this process is realized in non-diaphragm coolers, where strong heat and momentum exchange between hot exhaust gases 
and cold air injected from atmosphere takes place. While mixing, agents exchange energy on the heat tract, changing their enthalpy, [2,13]. Also the chemical composition of the exhaust changes.

In aviation there are two types of non-diaphragm exchangers, namely:

- non-diaphragm exchangers in which both agents are introduced into a common mixing chamber with a conveying equipment like pumps, fans, or compressors,

- non-diaphragm exchangers in which one of agents (usually cooling) is introduced into the mixing chamber due to ejection process caused by flow of a second agent (cooled).

The main advantage of this type of coolers is high intensity of heat transfer that allows to reduce their mass and dimensions.

An example of a non-diaphragm exhaust cooler, adapted to co-operate with the PZL 10W engine of the PZL W-3 helicopter was presented by Fijałkowski in [2]. Fig. 15 and Fig. 16 present general project of a desuperheater adapted to work on a board of PZL W-3 helicopter.

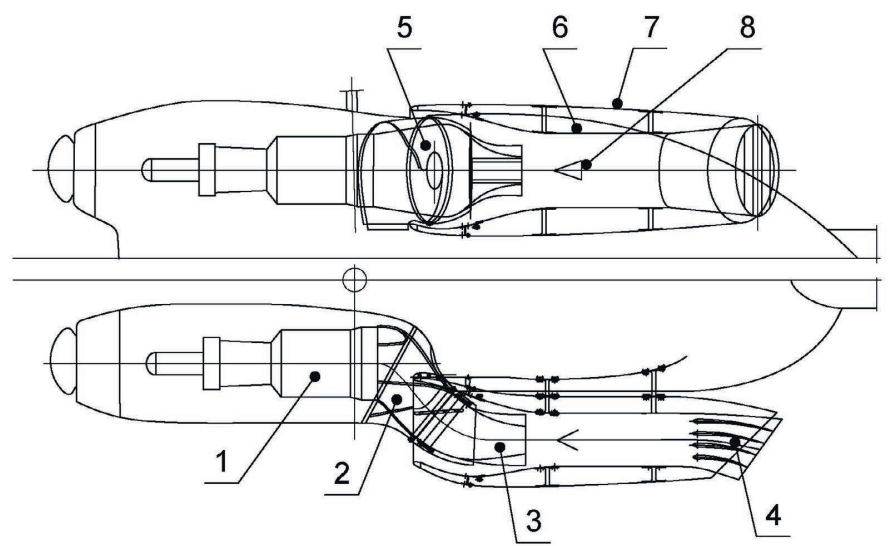

Fig. 15. Cross-section of side view of the cooler adapted to cooperate with PZL 10W engine on board of PZL W-3 helicopter: 1 - PZL 10W engine, 2 - modified exhaust diffuser (engine side), 3 - exhaust nozzle, 4 - desuperheater diffuser, 5 - heat shield of engine diffuser, 6 - desuperheater internal heat shield, 7 - desuperheater external heat shield, 8 - main swirler in mixing chamber, [2]

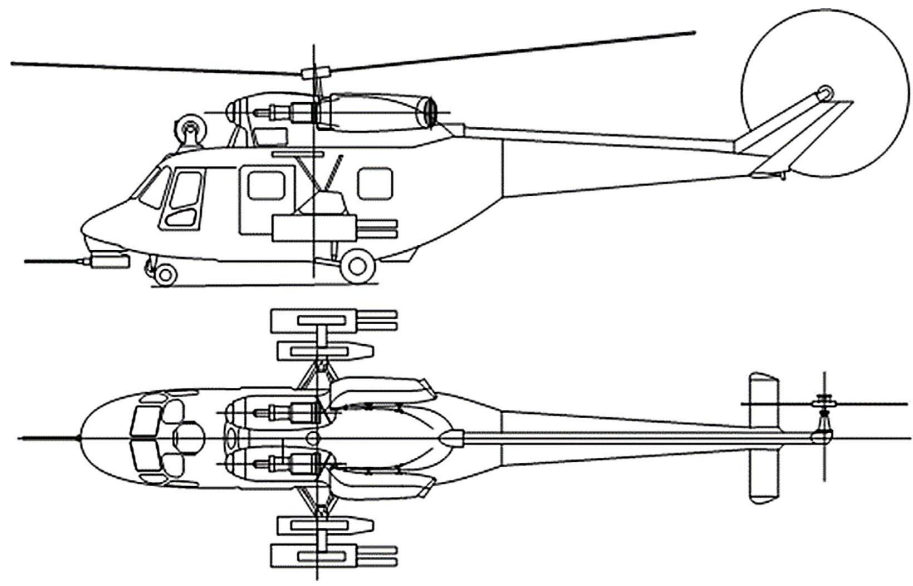

Fig. 16. Conceptional configuration of PZL W-3 helicopter equipped with exhaust desuperheater according to design from Fig. 15, [2] 


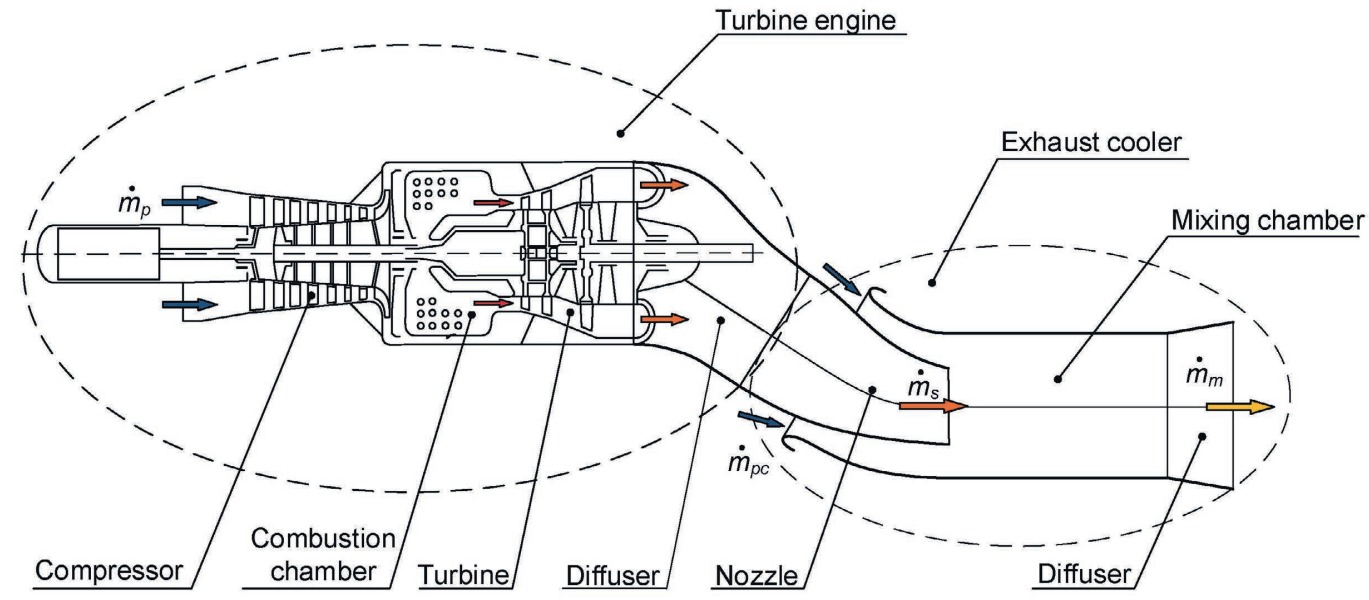

Fig. 17. General scheme of turbine engine - exhaust desuperheater system, [2]

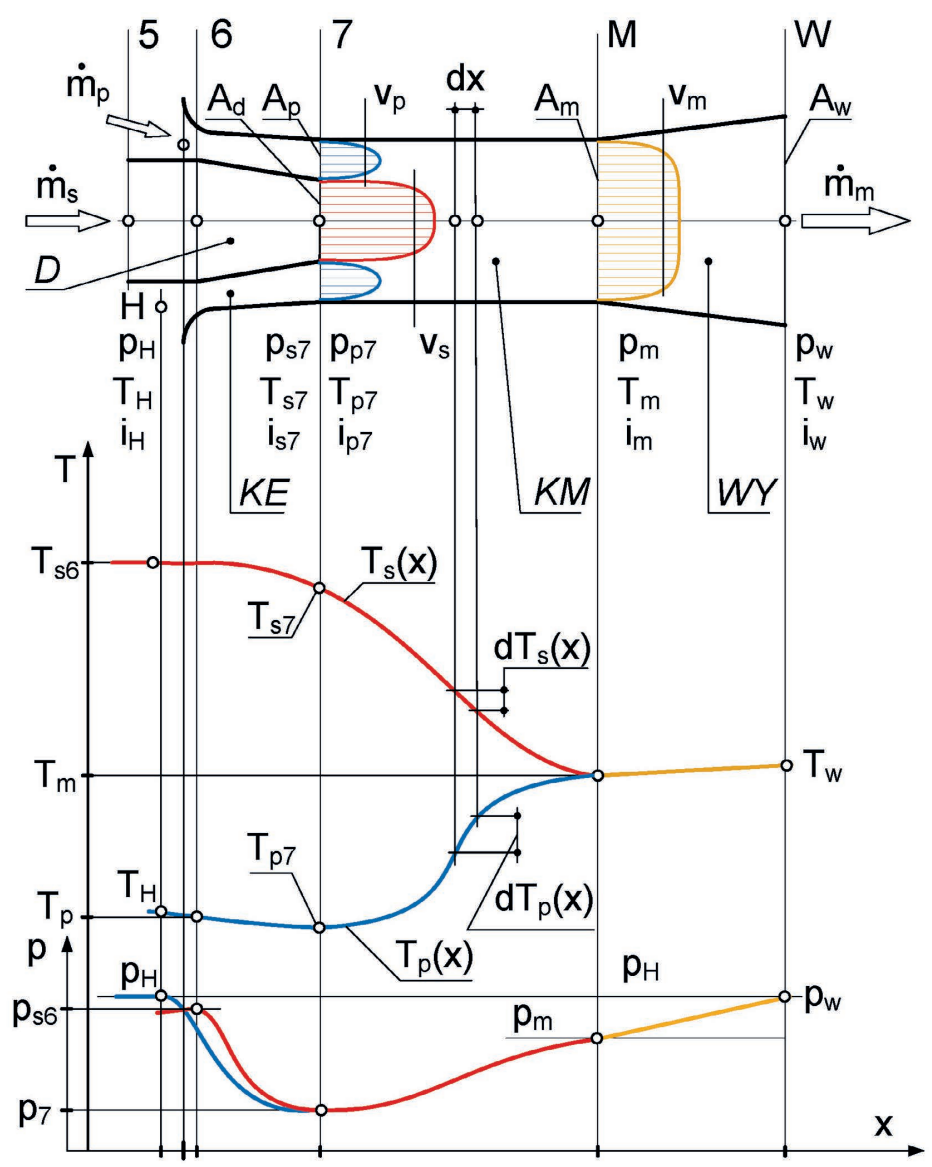

Fig. 18. Hypothetical distributions of pressures and temperatures of exhaust and atmospheric air in various sections of exhaust desuperheater, [1] 


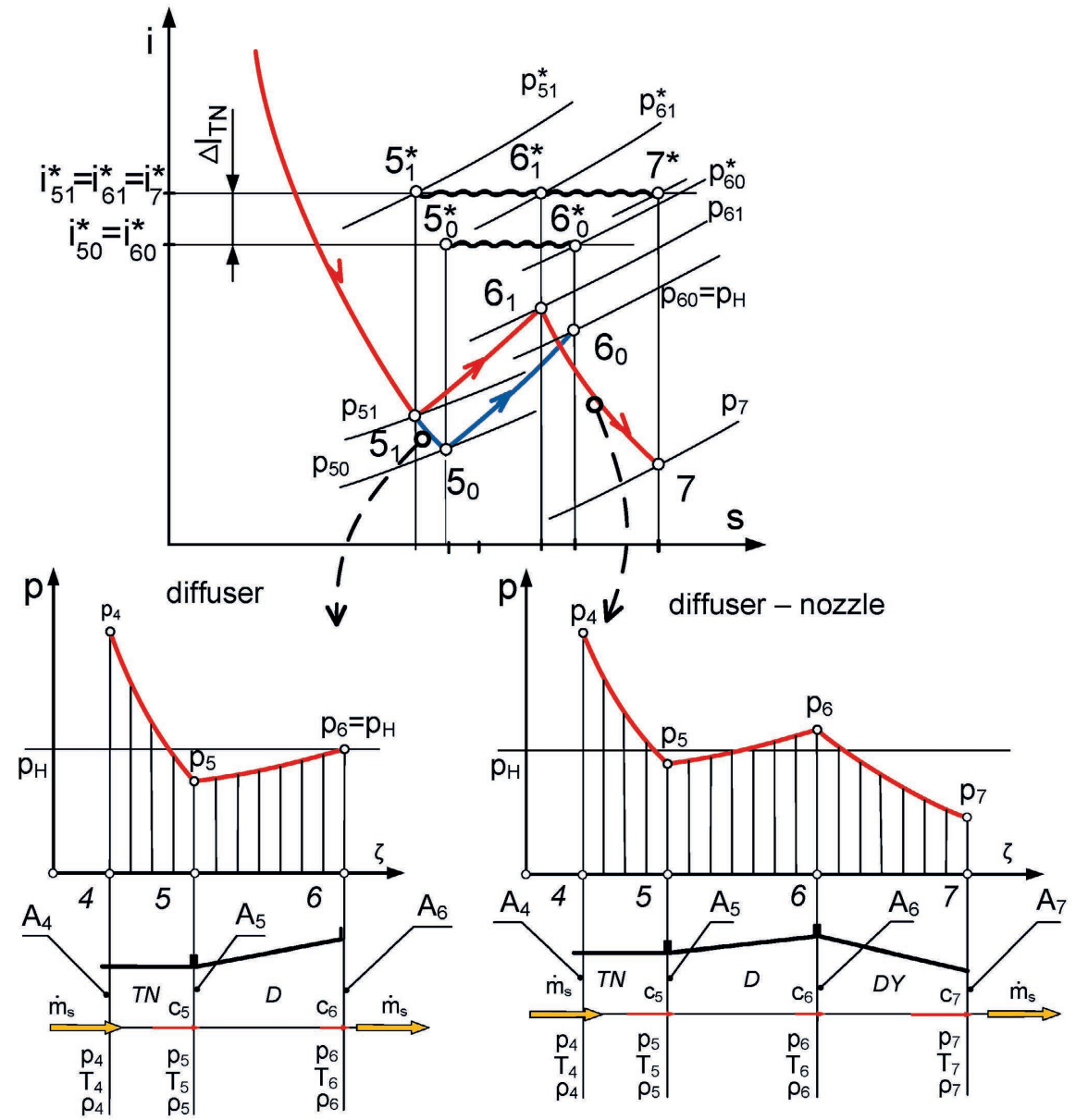

Fig. 19. Comparison of flow processes in section between power turbine and outlet section of engine exhaust system for two variants of helicopter engine exhaust system configuration, [14]

In general, conceptional helicopter exhaust cooler is formed by a modified turbine engine exhaust system, ejection chamber, mixing chamber and outflow diffusor (Fig. 17). Exhaust gases outflowing from power turbine are directed through diffusor to nozzle where their static pressure is lowered below the atmospheric pressure. As a result of exhaust static pressure decrease and velocity increase, suction of cold air stream into cooler flow channel succeed. In the mixing chamber, two streams undergo intensive mixing where strong heat and momentum exchange takes place. As a result of mixing hot exhaust with cold air injected from surrounding new stream is generated with significantly lowered temperature and changed chemical composition (Fig. 18).

Process of cold atmospheric air ejection into the cooler duct significantly depends on the static pressure level in engine exhaust system section. Application of nozzle in diffuser outlet section leads to static pressure decrease in engine outlet collector and consequently in cooler mixing chamber below the atmospheric pressure level. The lower static pressure in cooler duct the greater volume of external air ejected and consequently increase in efficiency of cooling. 
Simulation of PZL W-3 helicopter equipped with the cooler in selected NOE flight maneuvers was presented in [15]. The developed calculation program included calculations of the thermal and gas-dynamic parameters of the exhaust gases at the outlet section of the collector and calculating the process of cooling the exhaust gas in the cooler. As a result of the simulation, the values of the temperature and partial pressures of the mixture of exhaust gases and air outflowing to the environment were obtained. According to [15], use of exhaust gas coolers in helicopter turbine engine exhaust systems significantly reduces the cause of excessive infrared emissions and also changes the configuration of the exhaust streams in the environment. Thus, the range of static temperature variations in the outlet crossings of the exhaust systems depending on the helicopter maneuver is as follows: in the braking and returning maneuver - in the case of the classic exhaust system $607 \mathrm{~K}-690 \mathrm{~K}$, when using a cooler $344 \mathrm{~K}-372 \mathrm{~K}$, in the jump up maneuver - in the case of the classic exhaust system $641 \mathrm{~K}-720 \mathrm{~K}$, when using a cooler $355 \mathrm{~K}-383 \mathrm{~K}$, in the, the fast acceleration from hovering maneuver - in the case of the classic exhaust system $646 \mathrm{~K}-731 \mathrm{~K}$, when using a exhaust cooler $359 \mathrm{~K}-389 \mathrm{~K}$.

a.

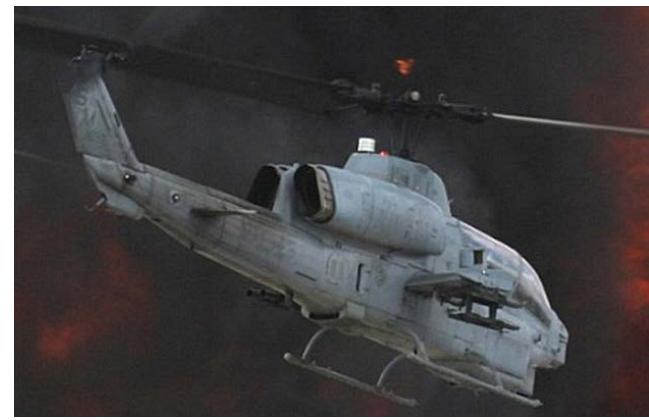

b.

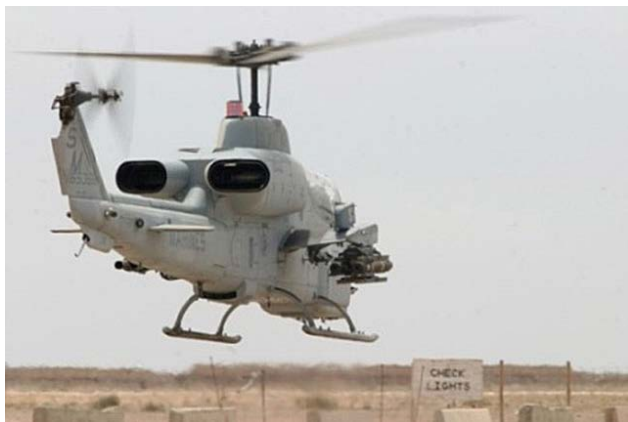

Fig. 20. AH-1 Super Cobra: a - without exhaust system modification , b - with HIRSS system, [21]

Another example of a non-diaphragm exhaust cooler is HIRSS (Hover InfraRed Suppression System) that has been developed to reduce the infrared emissions of the exhaust from helicopter engines, such as the General Electric T-700 engine employed in helicopter designs such as the Black Hawk UH-60, the Apache AH-64 and the AH-1. Example of HIRSS used on AH -1 Super Cobra version was shown below, where reflected thermal signature of tailboom was significantly decreased.

a.

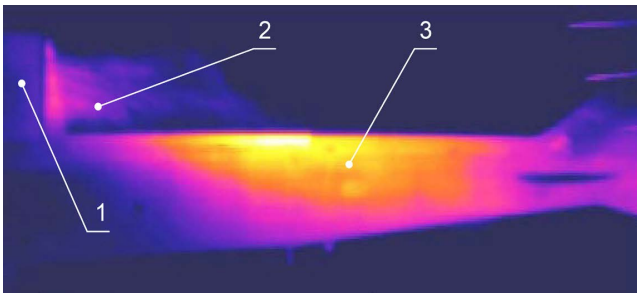

b.

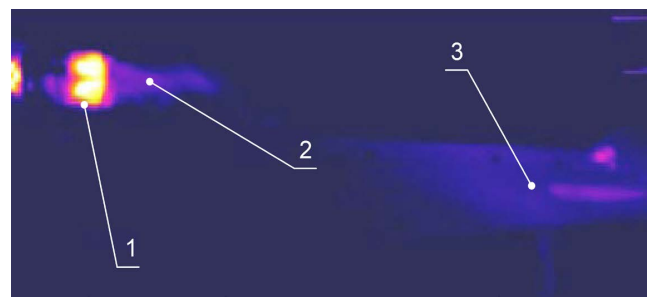

Fig. 21. AH-1 Super Cobra tailboom in infrared, a - without exhaust system modification, $b$ - with HIRSS system: 1 - exhaust diffuser, 2 - exhaust gases, 3 - tail boom, [11] 
The suppression system reduces infrared emission by recirculating hot engine exhaust gases within the suppressor core and mixing the heated gases with ambient air before discharging into the atmosphere.

Exhaust cooling system in AH- 64 Apache helicopter called Black Hole also works on the principle of atmospheric air ejection. The BH is a low-cost IR suppression system without any moving parts [16], as seen in Fig. 22.
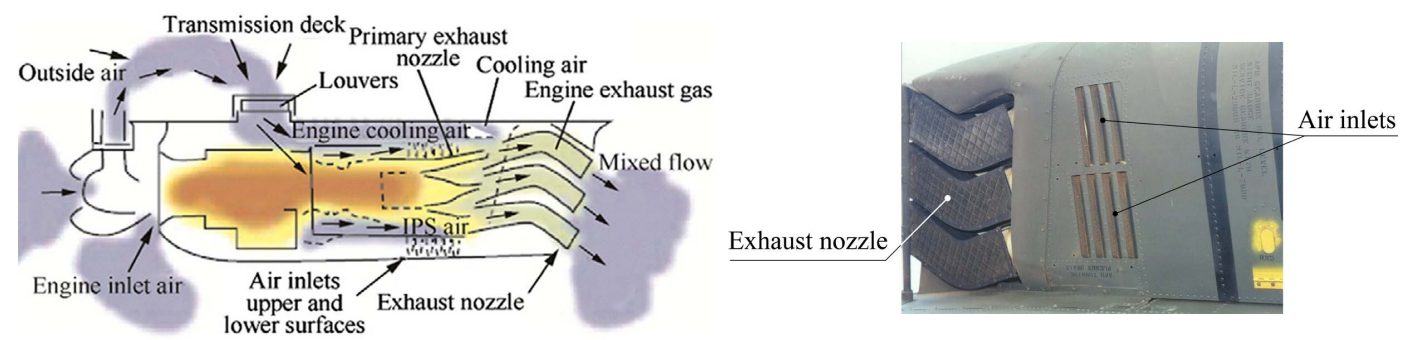

Fig. 22. Exhaust cooling system in AH-64 Apache, [17]

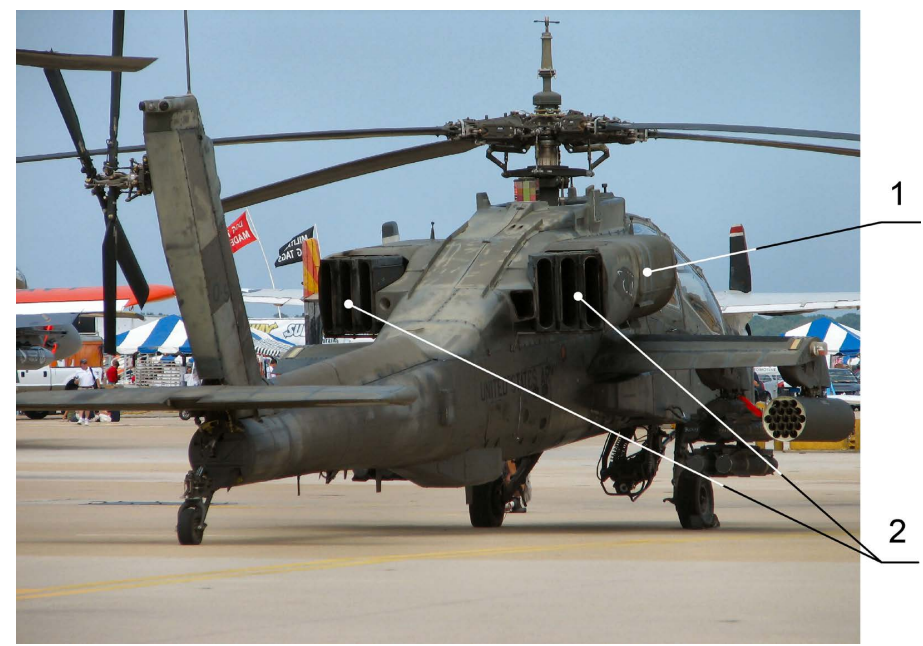

Fig. 23. AH-64 Apache rear view, 1 - engine, 2 - exhaust cooler, [21]

The principle of this system's operation is directing the engine exhaust through special ducts that connect the engine exhaust stream with a stream of a cold air passing over the helicopter. These channels ensure uniform outflow of exhaust stream which gives a better heat dissipation effect by the air stream. The fresh air-stream dissipates the hot exhaust that emerges from the vents evenly, rather than allowing hot spots to appear. Also, before leaving the Black Hole system, air-exhaust mixture is directed through a special insert made from heat absorbing material. 
In order to additionally improve the helicopter's thermal signature reduction, ejected fresh air is used to cool both the engines and the transmission. The engine exhaust nozzles are angled outward from the airframe to better direct the output into the air-stream and they are cooled with outside air from rotor downwash (while hovering in place) or with turbulent stream during progressive flight.

Mi -24 Hind is a Russian heavy attack helicopter. During the Afghan war, helicopters were modernized and they received complex self-defense systems. In the first phase, the thermal traps launchers (flares and metallic foil strips ASO- 2W) were added. Helicopters were also equipped with distracting shields EWU, designed to cool the exhaust gases. EWU reduced the exhaust gas temperature from $500-600{ }^{\circ} \mathrm{C}$ to $150-200{ }^{\circ} \mathrm{C}$ and helicopter thermal signature up to $60 \%$, [18]. The third system was the infrared active interference station $Ł 166 \mathrm{~W} 1 \mathrm{~A}$.

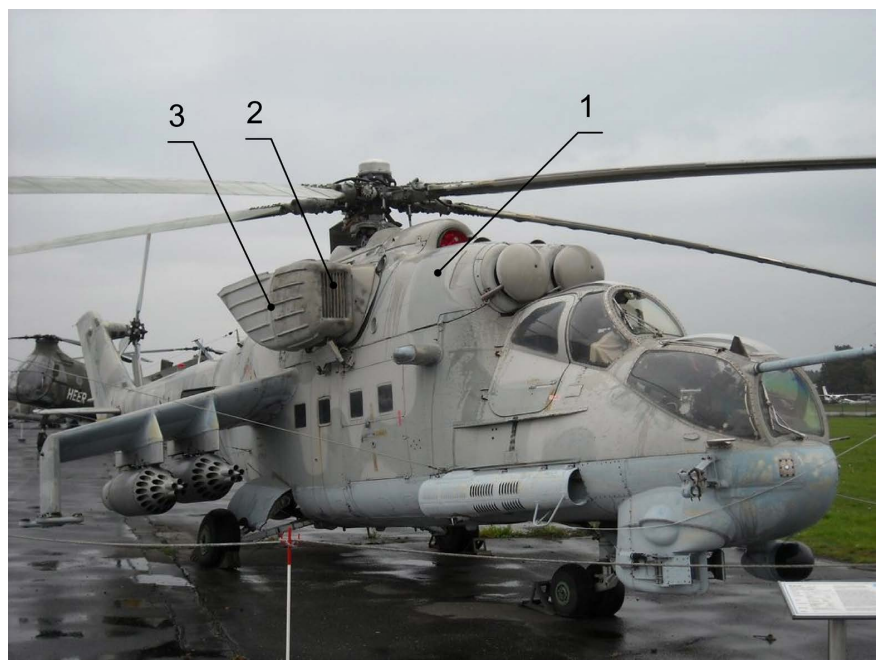

Fig. 24. Mi-24 Hind helicopter after modernization, 1 - engine, 2 - exhaust cooler air intake, 3 - exhaust cooler, [21]

The applied counter-measures of the Russian helicopters utilized in the described devices reduced losses in man and equipment to a significant low during fighting in Afghanistan. Before the modifications, the average accuracy of surface-to-air missiles fired was a hit of one out of ten fired, after the modifications just one out of a hundred fired hit the target.

The most advanced low-detectability helicopter is the prototype of RAH-66 Comanche (Fig. 25). It is mainly made from composites and it is covered with radar absorbent materials. To reduce the radar cross-section, the all-composite fuselage sides are flat and canted, and rounded surfaces are avoided by use of faceted turret and engine covers. The Comanche helicopter was equipped with an innovative method of infrared emission reduction, wherein the exhaust gases cooler is an integral part of the tail boom. In this solution, the exhaust outlet is disposed over the entire length of the tail boom providing fast, full and effective mixing of the hot exhaust gases and cold rotor downwash. The mixed exhaust is discharged through slots built into an inverted shelf on the sides of the tail-boom. 


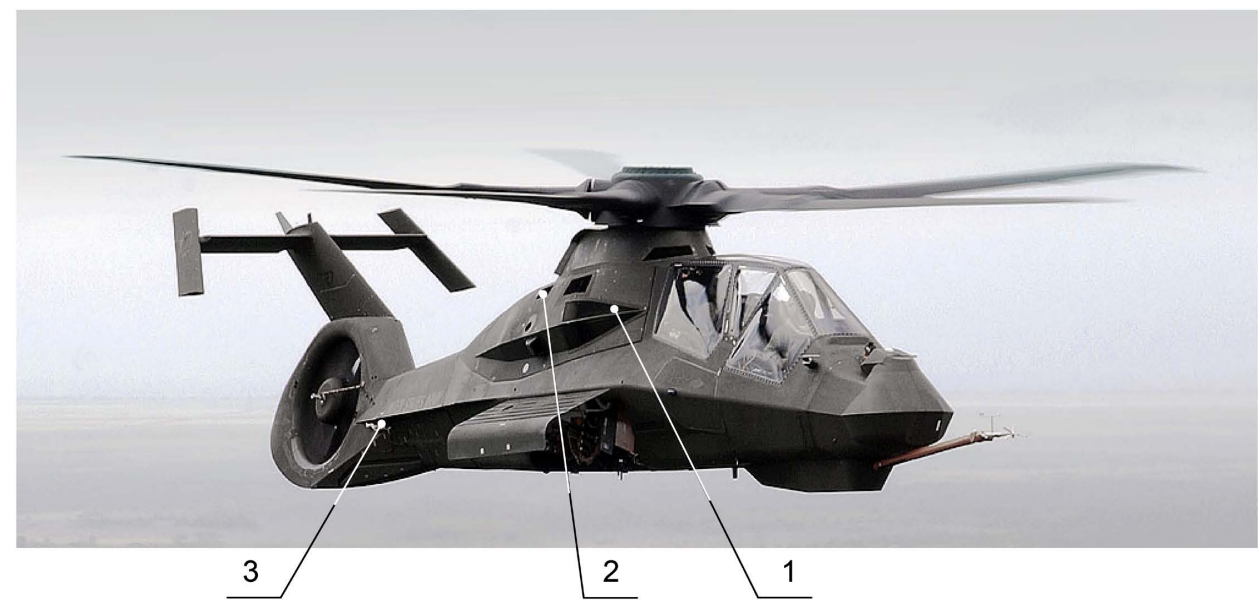

Fig. 25. RAH-66 Comanche prototype in flight: 1 - engine air intake, 2 - exhaust cooler air intake, 3 - exhaust system, [21]

Comanche's RCS was 360 times smaller than that of the AH-64 Apache attack helicopter, [19,20]. Because of that, the Comanche's chances of detection, tracking and destruction by heat-seeking missiles are negligible. Because of such an effective exhaust cooling system, the helicopter doesn't need an infrared band active jammer or interference generators.

\section{CONCLUSIONS}

The detection of helicopters on the battlefield significantly depends of their emission of infrared radiation, as well as the methods, equipment and systems enabling their detection by the enemy. Modern missiles equipped with guidance systems seeking infrared radiation sources are one of the most important threats to helicopters performing combat missions. The infrared suppression systems increase the aircraft's survivability by reducing the opportunity for an infrared signature seeking system to acquire, lock onto, track, and destroy the helicopter. Because of a high temperature, cooling of exhaust gases is a major tactic employed in aim to decrease infrared emissions by a helicopter in flight, but the most effective protection is a combination of all techniques, both passive and active.

\section{BIBLIOGRAPHY}

[1] Fijałkowski S., 2008, "Performance model of turbine engine exhaust cooler in extreme conditions helicopter flights. Part 1. Identification of membranneless exhaust gas cooler interaction with the helicopter turbine engine", Transactions of the Institute of Aviation 194-195 (in Polish).

[2] Fijałkowski S., 2011, “The Experiment - Based Analysis of the Infrared Emission by a Helicopter in Flight Transactions of the Institute of Aviation 211 (in Polish).

[3] Pan C., Zhang J., Shan Y., 2014, "Progress in helicopter infrared signature suppression”, Chinese Journal of Aeronautics 27(2): 189-199. 
[4] Mahulikar S.P., Rao G.A., Kolhe P.S., 2006, "Infrared signatures of low flying aircraft and their rear fuselage skin's emissivity optimization”, J Aircraft; 43(1): 226-32.

[5] Thompson J, Birk AM, Cunningham M., 1999, "Design of infrared signature suppressor for the Bell 205 (UH-1H) helicopters, Part I: aerothermal design”, Proceedings of seventh CASI propulsion symposium.

[6] Vass S., 2003, "Stealth Technology Deployed in battlefield”, AARMS.

[7] Zikidis K., Skondras A., Tokas C., 2014, "Low Observable Principles, Stealth Aircraft and Anti-Stealth Technologies", Journal of Computations \& Modelling, vol.4, no.1, 129-165.

[8] Fijałkowski, S., 2011, "Identifying the Behaviour of a Jet Stream in the Environment After Leaving a Helicopter Engine Diffuser in Flight", Transactions of the Institute of Aviation 219 (in Polish).

[9] Fijałkowski S., Kania M., 2011, "Numerical Model of Exhaust Gases Expansion in Rotor Wake Vortex During Vertical Helicopter Flight", Transactions of the Institute of Aviation 221 (in Polish).

[10] Pan C., Zhang J., Shan Y., 2014, "Effects of rotor downwash on exhaust plume flow and helicopter infrared signature", Applied Thermal Engineering 65(1-2): 135-149.

[11] Groninga K., 2005, “Development and implementation of the H-1 turned exhaust system”, AHS Texas.

[12] Fijałkowski S., 2013, “The Conditions for Cooling Termovision in the Turbine Engine Propulsion Helicopter in Varied Flight Conditions", Transactions of the Institute of Aviation 230 (in Polish).

[13] Szumański K., 2001, "Helicopters tests during extreme tasks", Transactions of the Institute of Aviation 165-166 (in Polish).

[14] Fijałkowski S., "The Impact of the Change in the Geometry of an Exhaust Gas Outlet Mainfold on the Operation of a Helicopter Turbine Engine", Transactions of the Institute of Aviation 219 (in Polish).

[15] Fijałkowski S., Wójcik P., 2008, "Performance model of turbine engine exhaust cooler in extreme conditions helicopter flights. Part 2. Performence simulation of exhaust cooler in helicopter flight extreme conditions", Transactions of the Institute of Aviation 194-195 (in Polish).

[16] Kuck K., 2005, „Commercial Operations and Support Saving Initiative for the OH-58D Kiowa Warrior", AHS Texas.

[17] Barlow B., Petach A., 1977, "Advanced design infrared suppressor for turbo-shaft engines," Proceedings of the 33rd annual national forum of the American helicopter society.

[18] Butowski P., Gruszyński J., Fiszer M., 2006, „Śmigłowiec bojowy Mi-24”, Wydawnictwo Magnum X, Warszawa.

[19] Bonds R., Miller D., 2002, “Boeing Sikorsky RAH-66 Comanche”, Illustrated Directory of Modern American Weapons. Grand Rapids, Michigan.

[20] Siuru W., Busick J.D., (1993). “Future Flight: The Next Generation of Aircraft Technology”, McGraw-Hill Professional.

[21] Internet sources:

http://www.aircav.com/cobra/ahgal24/ah1w-070517.html

http://www.richard-seaman.com/Wallpaper/Aircraft/Helicopters/SuperCobraAndWallOfFire1.jpg http://www.boeing.com/history/products/rah-66-comanche.page

http://www.globalsecurity.org/military/world/russia/mi-24-pics.htm 


\title{
METODY OGRANICZANIA EMISJI PODCZERWIENI WE WSPÓŁCZESNYCH ŚMIGLOWCACH WOJSKOWYCH
}

\begin{abstract}
Abstrakt
Śmigłowce odgrywają niezwykle istotną rolę w krótkodystansowych walkach powietrznych jak również jako wsparcie ogniowe na cele naziemne, szczególnie w trakcie operacji przeciw pojazdom opancerzonym. Wykrywalność oraz żywotność śmigłowców na polu walki istotnie zależy od poziomu emisji podczerwieni emitowanej z ich pokładu jak również od metod, urządzeń i systemów detekcji wykorzystywanych przez przeciwnika. Współczesne systemy wykrywania, rozpoznawania i identyfikacji obiektów latających wykorzystują szereg metod termolokacyjnych, które polegają na wykrywaniu promieniowania podczerwonego emitowanego przez śledzony obiekt. W śmigłowcowej technice lotniczej, szczególnie istotna jest emisja podczerwieni z gazów spalinowych odprowadzanych do otoczenia. Ze względu na ich wysoką temperaturę, gazy spalinowe stanowią główne źródło emisji podczerwieni przez śmigłowiec w locie co w połączeniu ze stosunkowo niską prędkością oraz wysokością wykonywanych manewrów, czyni śmigłowce łatwymi celami dla współczesnych rakiet wyposażonych w głowice samonaprowadzające się na podczerwień. W celu zwiększenia bezpieczeństwa, efektywności oraz żywotności śmigłowców wojskowych wykonujących lotne zadania bojowe, opracowany został szereg metod redukcji poziomu emisji promieniowania podczerwonego. W niniejszej pracy przedstawiono przegląd współczesnych osiągnięć w tej dziedzinie wraz z prezentacją systemów maskowania podczerwieni stosowanych we współczesnych śmigłowcach wojskowych.
\end{abstract}

Słowa kluczowe: podczerwień, śmigłowiec wojskowy, stealth, maskowanie promieniowania. 